\title{
INTELLECTUAL CAPITAL DISCLOSURES AND CORPORATE GOVERNANCE: AN EMPIRICAL EXAMINATION
}

\author{
Dr. Mohammad Badrul Muttakin \\ Department of Accounting \\ Deakin University \\ 221 Burwood Highway \\ Victoria 3125, Australia \\ Email: m.muttakin@deakin.edu.au \\ Phone: 61-03-92517826
}

Dr. Arifur Khan

Department of Accounting

Deakin University

221 Burwood Highway

Victoria 3125, Australia

Email: arifur.khan@deakin.edu.au

Phone: 61-03-92446857

and

Dr. Ataur Rahman Belal

Aston Business School

Aston University

Birmingham B4 7 ET, UK

Email: a.r.belal@ aston.ac.uk

Phone: +44(0)1212043031

Forthcoming in Advances in Accounting

Corresponding Author: Dr.Arifur Khan

Department of Accounting

Deakin University

221 Burwood Highway

Burwood, Victoria 3125

Australia

Email: arifur.khan@ deakin.edu.au Phone: 61-03-92446857 


\begin{abstract}
Empirical examinations of the links between corporate governance and intellectual capital are under researched, particularly from the context of emerging economies where corporate governance mechanisms tend to be largely ceremonial due to family dominance. This study aims to address this gap in the intellectual capital disclosure (ICD) literature by undertaking an empirical examination of the relationship between corporate governance and the extent of ICD of Bangladeshi companies. Inter alia, the key findings of this study suggest that there is a non-linear relationship between family ownership and the extent of ICD. This research also found that foreign ownership, board independence, and the presence of audit committees are positively associated with the extent of ICD. Conversely, family duality (i.e., where the positions of CEO and chairperson are occupied by two individuals from the same family) is negatively associated with the extent of ICD.
\end{abstract}

Keywords: Intellectual capital disclosure, corporate governance, family ownership, family duality, CEO duality, agency theory, Bangladesh 


\section{Introduction}

In today's knowledge based economies, intellectual capital (in addition to financial and physical capital) plays a significant role in the value creation process of organizations. It is argued that the success of many $21^{\text {st }}$ century organizations lies in their ability to unlock and exploit their intellectual capital to obtain maximum "organizational advantage" (Keenan \& Aggestam, 2001; Nahapiet \& Ghoshal, 1998). Keenan and Aggestam (2001) were among the earliest authors to identify conceptual links between corporate governance and intellectual capital. They argued that decision makers in charge of the corporate governance of an organization have a "fiduciary responsibility" to utilize the full advantage of intellectual capital, in addition to financial and physical capital. However, empirical knowledge in relation to the conceptual link between corporate governance and intellectual capital is limited. This study aims to contribute to the field of research on intellectual capital disclosure (ICD) (see for example, Cerbioni \& Parbonetti, 2007; Hidalgo, García-Meca, \& Martínez, 2011; Li, Pike, \& Haniffa, 2008) by examining the relationship between various corporate governance attributes and the extent of ICD.

In one of the earliest empirical studies on European biotechnology, Cerbioni and Parbonetti (2007) found that board structure, independence and Chief Executive Officer (CEO) duality (i.e., when the same 
individual is both the CEO and chairperson of the board) are related to ICD. Subsequently, in the United Kingdom, Li et al. (2008) confirmed these relationships with the exception of CEO duality. It appears that the study of Hidalgo et al. (2011) is the only empirical study that explored the relationship between corporate governance and the extent of ICD in a developing country (i.e., Mexico). They also introduced a new corporate governance attribute; that is, family ownership. Their findings suggested that family ownership does not influence the extent of ICD in Mexican companies. One possible reason for this result is that Hidalgo et al. (2011) did not test for a non-linear relationship between family ownership and the extent of ICD; however, this relationship can be established via a quadratic specification of family ownership (which was undertaken in this paper).

This study was conducted in Bangladesh. Scarce empirical evidence exists in respect of the relationship between corporate governance attributes and the extent of ICD. ${ }^{1}$ Further, for the most part, previous Bangladesh studies have been descriptive in nature and used relatively small samples; for example, Ali, Khan, and Fatima (2008) found that ICD is mostly disclosed in a narrative form in annual reports and concluded that Bangladeshi companies do not have a positive approach to reporting ICD. Similarly, Khan and Khan (2010), Nurunnabi, Hossain and Hossain (2011) and Rashid (2013) found that Bangladeshi 
companies provide limited ICD in annual reports, as it is not a mandatory requirement to report on this in Bangladesh. In a recent study in the pharmaceutical industry, Abhayawansa and Azim (2014) found that companies did not adopt a consistent framework for ICD and did not properly measure and manage their ICD.

This research was conducted in Bangladesh, as it provided an interesting context for the study. The corporate context of Bangladesh is characterized by relatively small capital market, small firm size, and family dominated ownership structures. Like many other emerging economies, Bangladesh has adopted a western-style corporate governance model that requires greater board independence, separation of the CEO and chairperson, and audit committees. In 2006, the Bangladeshi Securities and Exchange Commission (SEC) issued a "Corporate Governance Notification" (SEC, 2006) that provides guidelines for corporate governance practices by listed companies on a "Comply or Explain basis.", However, given the traditional nature of its society (Uddin \& Choudhury, 2008), and in circumstances where family ownership is the major form of business in Bangladesh, the efficacy of such corporate governance mechanisms could be compromised. Indeed, previous research (Sobhan \& Werner, 2003) has reported that due to family dominance, corporate governance mechanisms tend to be largely ceremonial. ${ }^{3}$ Additionally, there are no legislative guidelines for ICD in 
Bangladesh ${ }^{4}$. Thus, the influence of corporate governance dynamics on ICD may be different in developing countries such as Bangladesh (Rashid, 2013).

This study can be distinguished from previous research and contributes to the literature in a number of ways. First, while exploring the relationship between corporate governance attributes and ICD it also tests the effect of family ownership on ICD (a relationship which has been understudied in the previous ICD research, but is significant in the context of Bangladesh). In this respect, the non-linear relationship between family ownership and ICD is examined. Second, this study is the first study in the ICD literature to consider the effect of family duality, which is very common in emerging economies, on ICD. Third, to date, the majority of studies have examined the effect of corporate governance attributes on ICD in a Western socio-political context; however, this study focuses on an emerging market, characterized by weak institutional framework and a high concentration of family ownership. Finally, the findings of this study increase understanding in relation to corporate governance attributes and ICD practices and extend the findings of previous descriptive Bangladeshi studies that mainly focused on the extent and content of ICD. 
The remainder of this paper is structured as follows. In section 2, a literature review is undertaken and hypotheses are developed. Section 3 then explains the research design for this study, including details of the sample, measurement of the variables and the data analysis procedures. Next, the penultimate section of the paper presents the core empirical results of the analysis. Finally, the last section of the paper contains a summary of the results and offers some concluding thoughts.

\section{Literature review and hypotheses development}

In this literature review section, previous research on the relationship between corporate governance and ICD is considered. This section aims to contribute to the stream of ICD literature that examines the relationship between corporate governance and ICD. Based on this discussion, six hypotheses were developed for testing.

\subsection{Family ownership}

It is argued that agency problems, characterized by a conflict of interest between owners and managers (hereafter referred to as "type I" agency problems) are less of an issue in family owned organizations (Anderson \& Reeb, 2004). However, substantial agency problems may occur in family owned organizations attributable to conflict between controlling family owners and minority shareholders (hereafter referred to as "type II" agency problems) (Villalonga \& Amit, 2006). Given the absence of 
type I problems in family owned organizations, family owners can mitigate agency problems. Concentrated ownership motivates family members to maximize the wealth of all shareholders and the opportunistic behavior of family members for personal gains is restricted by their long-term investment horizon, concern for their reputation and higher interest in the firm. Consequently, it appears more likely that family owned organizations would be concerned with information transparency. This, in turn, should result in a positive relationship between family ownership and the extent of ICD. Conversely, the presence of type II agency problems suggests that family owners may exacerbate this agency problem. Previous research on family businesses suggested that an increase in family ownership beyond a certain percentage could be detrimental for a firm, as the additional percentage of ownership leads to entrenchment and entrenched family owners tend to expropriate minority shareholders. Further, such concentrated ownership enables these family owners to dominate the firm and determine the strategies and policies for voluntary disclosures, including ICD. Caring less about information transparency may also result in less ICD. It is anticipated that this type of agency problem is very common in Bangladesh due to poor institutional and legal frameworks. Further, because the level of public interest in family owned firms is expected to be relatively low, these types of firms are likely to experience less pressure from minority shareholders in relation to the voluntary 
provision of ICD. Accordingly, managers of family owned firms might not invest heavily in ICD because the costs of investing in these activities may far outweigh the potential benefits.

It is posited that the combination of the effects of type I and type II agency problems will result in a non-linear relationship between family ownership and the extent of ICD. A quadratic specification of family ownership variable is used in this research. It is expected that any increase in family ownership (up to a certain percentage of ownership) will also result in an increase in the extent of voluntary ICD disclosure. It is also anticipated that at this ownership level there will be less type I problems, as any increase in share ownership is likely to align family interests with the interests of general shareholders. However, it is also predicted that beyond a certain percentage of ownership, any increase in family ownership will make the family members entrenched and type II problems may arise. At this ownership level, a negative relationship between family ownership and the extent of voluntary ICD disclosure is expected. This above reasoning led to the following hypothesis:

H1: There is a positive association between family ownership and the extent of ICD up to a certain level of ownership which is followed by a negative association between family ownership and the extent of ICD. 


\subsection{Foreign ownership}

Previous studies have suggested that the percentage of foreign ownership influences the extent of voluntary disclosures (Al-Akra, Eddie, \& Ali, 2010; Haniffa \& Cooke, 2002). Due to language barriers, lack of local contextual knowledge and the geographical separation between management and owners, foreign investors are likely to face a higher level of information asymmetry (Haniffa \& Cooke, 2002). Thus, it is expected that foreign investors will demand more voluntary disclosures, including ICD. It is also expected that foreign investors in emerging markets, such as Bangladesh, will demand a higher extent of disclosures from companies, as these investors face more uncertainty and unfamiliarity than local investors (Al-Akra, et al., 2010). Accordingly, it is likely that foreign investors will influence the corporate disclosure practices, including ICD, of Bangladeshi companies. In the light of this discussion, the following hypothesis is proposed:

H2: There is a positive association between foreign ownership and the extent of ICD.

\subsection{Board independence}

Board independence is defined as the proportion of independent directors to the total number of directors (Haniffa \& Cooke, 2002). 
Independent directors are needed on boards to monitor and control the opportunistic behavior of executive directors (Jensen \& Meckling, 1976). Corporate governance mechanisms can be strengthened by the presence of independent directors on boards. Fama and Jensen (1983) argued that independent directors also act as an internal governance mechanism to reduce agency conflicts between managers and owners by encouraging management to disclose more information. Other research has shown that a positive relationship exists between board independence and the extent of ICD ( $\mathrm{Li}$ et al., 2008, Cerbioni \& Parbonetti, 2007). However, a recent study by Hidalgo et al. (2011) found that there was no relationship between board independence and the extent of ICD. It is argued that in Bangladesh, purportedly "independent" directors are not truly independent and often fail to make disclosures. Sobhan and Werner (2003) noted that directors classed as being "independent" in Bangladesh were often former bureaucrats who had vested interests in the companies to which they had been appointed. This observation resonates with the findings of Uddin and Choudhury (2008) that independent directors are often appointed due to "personal connections"; rather than skills and expertise. Such appointments may affect the ability of directors in Bangladesh to operate independently. Thus, this research tests relationship between board independence and the extent of ICD with the following hypothesis: 
H3: There is a positive association between proportion of independent directors on board and the extent of ICD.

\subsection{CEO duality}

As stated above, CEO duality refers to situations in which one individual is both the CEO and chairperson of a board. In these circumstances, managerial dominance is greatly enhanced, as such individuals are more aligned with management than shareholders. CEO duality may constrain board independence and reduce the ability of boards to execute their oversight and governance roles (Finkelstein \& D'aveni, 1994). Additionally, CEO duality gives CEOs the power to negotiate with boards and may allow CEOs to pursue self-serving interests. Gul and Leung (2004) found that CEO duality resulted in lower voluntary disclosure, as in these circumstances boards were less effective at monitoring management and ensuring high levels of transparency. Similarly, Cerbioni and Parbonetti (2007) found that a negative relationship existed between CEO duality and ICD. However, Li et al. (2008) and Hidalgo et al. (2011) did not find any significant relationship existed between CEO duality and the extent of ICD. SEC guidelines (2006) in Bangladesh require the positions of chairperson of the board and CEO to be separate. Given the regulatory context in Bangladesh, this study examines whether CEO duality has any impact on the extent of ICD. It is hypothesized that: 
H4: There is a negative association between CEO duality and the extent of ICD.

\subsection{Family duality}

It is also possible that "family duality" may occur in family owned organizations. Family duality is defined as the situation in which two members of the one family occupy the positions of CEO and chairperson (i.e., the two most influential positions) on a board. An earlier study by Prencipe, Bar-Yosef, Mazzola, and Pozza (2011) contended that family duality ensures the alignment of the board's interest with the interest of general shareholders. They also noted that income smoothing is less likely to occur when the CEO and the chairperson are the members of the same family.

It is arguable that family duality may lead to situations in which top company management protects family interests over the interests of the general shareholders. In Bangladesh, family duality is very common and two close family members often hold the two top positions in an organization (e.g., a father as the chairperson and a son as the CEO). Indeed, Mazumder (2006) reported that barring multinational companies, the majority of listed companies in Bangladesh are dominated by family members, whereby the head of the family is the chairperson and other family members occupy important posts such as 
CEO or managing director. Given the poor institutional and legal frameworks and the low level of public interest in family firms in Bangladesh, family duality may lead to management being less concerned about capital market and voluntary ICD. Thus, it is hypothesized that:

H5: There is a negative association between family duality and the extent of ICD.

\subsection{Audit committees}

It is well established in the corporate governance literature that an audit committee is an effective corporate governance mechanism (Turley \& Zaman, 2007). As an internal governance mechanism, an effective audit committee should improve internal control, act as a means of attenuating agency costs, and be a powerful monitoring device for improving ICD (Li et al., 2012). Notably, audit committees have been found to be associated with more reliable financial reporting, enhanced quality and increased disclosure (Ho \& Shun Wong, 2001). Li, Mangena, and Pike (2012) and Li, et al. (2008) found a positive relationship existed between audit committee characteristics, including the size and frequency of meetings and the extent of ICD. Similarly, in the context of emerging economies, Pomeroy and Thornton (2008) reported that a positive 
relationship exists between audit committee and financial reporting quality.

The current legislative framework of Bangladesh, embodied in SEC (2012), requires at least two audit committee members be independent directors. It also requires the chair of audit committees to be a professional with accounting and financial expertise. Nonetheless, Khan et al. (2013) documented that more than 50 percent of Bangladeshi companies do not have audit committees. Given the prevailing family dominated corporate culture in Bangladesh, it is unlikely that audit committees would have significant influence on disclosure practices in Bangladesh, particular in relation to ICD. However, the presence of at least two independent directors on an audit committee could mitigate some of the influences of the presence of family members on a committee. Accordingly, it is hypothesized that:

H6: There is a positive association between the presence of audit committees and the extent of ICD.

\section{Research Method}

\subsection{Sample and data}

The sample consists of 135 non-financial companies ${ }^{5}$ listed on the Dhaka Stock Exchange (DSE). Due to missing information for corporate 
governance attributes 19 firms have been excluded. The final sample comprises the remaining firms, with a total of 580 firm-year observations over a five-year period (2005-2009). Since there is no annual report database available in Bangladesh, 2005 was furthest year the authors could go back in the past. Furthermore, 2009 was the latest year of annual reports available when the research project began. The annual reports of the sample companies have been collected from various sources including DSE and company specific web sites. The data for corporate governance attributes, financial and intellectual capital were hand collected from the annual reports. The sample firms belong to a wide range of sectors such as cement, ceramics, engineering, food, jute, paper and printing, miscellaneous, pharmaceuticals, tannery, paper and printing and textile.

\subsection{Model specification}

This study uses a regression analysis technique to examine the relationship between the corporate governance variables and the extent of ICD. The regression equation is provided below:

$$
\begin{aligned}
& \text { ICDI }_{i t}=\alpha+\beta_{1} \text { FOWN }_{i t}+\beta_{2} \text { FOWN }_{i t}^{2}+\beta_{3} \text { FOROWN }_{i t}+\beta_{4} \text { BIND }_{i t} \\
& +\beta_{5} \text { CEODU }_{i t}+\beta_{6} \text { FAMDU }_{i t}+\beta_{7} \text { AUDCOM }_{i t}+\beta_{8} \text { FSIZE }_{i t}+ \\
& \beta_{9} \text { FAGEit }+\beta_{10} \text { LEV }_{i t}+\beta_{11} \text { ROA }_{i t}+\sum_{I=1}^{11} \beta_{12} \text { INDUSTRY DUMMIES }_{i} \\
& +\sum_{I=I}^{5} \beta_{13} \text { YEAR DUMMIES }_{t}+\varepsilon_{i t}
\end{aligned}
$$


Where

\begin{tabular}{|c|c|c|}
\hline ICDI & $=$ & Intellectual capital disclosure score/ index \\
\hline FOWN & $=$ & $\begin{array}{l}\text { percentage of shares owned by the family } \\
\text { members }\end{array}$ \\
\hline FOROWN & $=$ & $\begin{array}{l}\text { percentage of shares owned by the foreign } \\
\text { investors }\end{array}$ \\
\hline BIND & $=$ & proportion of indirect directors on the board \\
\hline CEODU & $=$ & $\begin{array}{l}\text { dummy variable equals } 1 \text { if same person } \\
\text { holds the positions of CEO and chairperson } \\
\text { in a firm }\end{array}$ \\
\hline FAMDU & $=$ & $\begin{array}{l}\text { dummy variable equals } 1 \text { if } 2 \text { persons from } \\
\text { the same family hold the positions of CEO } \\
\text { and chairperson in a firm }\end{array}$ \\
\hline AUDCOM & $=$ & $\begin{array}{l}\text { dummy variable equals } 1 \text { if there is an audit } \\
\text { committee in a firm }\end{array}$ \\
\hline FSIZE & $=$ & natural logarithm of total assets \\
\hline FAGE & $=$ & $\begin{array}{l}\text { natural } \log \text { of the number of year since the } \\
\text { firm's inception }\end{array}$ \\
\hline LEV & $=$ & $\begin{array}{l}\text { ratio of book value of total debt and total } \\
\text { assets }\end{array}$ \\
\hline ROA & $=$ & $\begin{array}{l}\text { ratio of earnings before interest and taxes } \\
\text { and total assets }\end{array}$ \\
\hline
\end{tabular}

\subsection{Dependent Variable- intellectual capital disclosure index (ICDI)}

The intellectual capital disclosure index (ICDI) represents the dependent variable in this study. Joseph and Taplin (2011) referred to this disclosure measurement approach as 'disclosure occurrence' that captures the breadth of disclosure as opposed to the depth of disclosure 
captured via volumetric method. According to Nurhayati, Brown, and Tower (2006) ICDI is a more suitable measure for developing countries where disclosures tend to be low.

To assess the extent of ICD in the annual reports, a checklist containing 32 items has been constructed (see Appendix II). One of the limitations of prior ICD studies is that they do not provide the detailed explanation of the items and coding rules used to allocate information to intellectual capital categories (Beattie \& Thomson, 2007). This study provides the details of the items in the checklists and coding rules used so that it can facilitate the interpretation of the findings. This study follows previous developing country studies (see for example, Abeysekera and Guthrie (2005), Abeysekera (2008a), Rashid (2013)) to develop a modified checklist including the items relevant to Bangladeshi companies. A dichotomous procedure is applied whereby a company is awarded 1 if an item included in the checklist is disclosed and 0 if it is not disclosed. Accordingly, intellectual capital disclosure index (ICDI) is derived by computing the ratio of actual scores awarded to the maximum score attainable (32) by that company. ${ }^{6}$ Consistent with Haniffa and Cooke (2005) and $\mathrm{Li}$, et al. (2008) the index is measured for each company as the ratio of the score obtained to the maximum possible score relevant for that company. 
To examine the internal consistency of the disclosure index this study has used Cronbach's coefficient alpha (Cronbach, 1951) which is 0.621 and consistent with Botosan (1997) and Gul and Leung (2004). Internal consistency refers to the degree to which the items in a test measure the same construct. Botosan (1997) and Gul and Leung (2004) uses the coefficient alpha as a reliability statistics useful to assess the degree to which correlation among the information categories of the disclosure index is attenuated due to random error. Cronbach's coefficient alpha of this study provides a good support that the set of items in the disclosure scoring index capture the same underlying construct.

\subsection{Hypothesized and control variables}

The hypothesized corporate governance variables are family ownership (FOWN), foreign ownership (FOROWN), board independence (BIND), CEO duality (CEODU), family duality (FAMDU) and audit committee (AUDCOM). This study uses a quadratic specification of FOWN variable since a non-linear relation between family ownership and the extent of ICD is hypothesised. This study also includes a number of control variables that have been found in prior research to be related to ICD. The control variables included are firm size (FSIZE), firm age (FAGE), leverage (LEV) and return on assets (ROA). Larger firms are complex nexus and there could be conflict between the managers and shareholders (Inchausti, 1997), therefore increasing agency costs. In 
order to mitigate these costs, these companies will disclose more voluntary information including information on intellectual capital. A more matured firm is concerned about its reputation and hence disclose more voluntary information. The companies with higher leverage have higher agency costs due to high risk surrounding them (Jensen \& Meckling, 1976). Thus creditors and other external parties demand more disclosures to reduce information asymmetry (Arvidsson, 2003). Profitable companies disclose more intellectual capital information (Ousama, Fatima, \& Hafiz-Majdi, 2012). Finally, this study also uses year dummies and industry dummies for different sectors.

\section{Results and Analysis}

Table 1 provides the descriptive statistics for the variables used in the study. The average intellectual capital disclosure score (ICDI) is 0.155 (median $=0.125)$. The average scores for internal capital disclosure (INTDCI), external capital disclosure (EXTCDI) and human capital disclosure (HUMCDI) are $0.137,0.115$ and 0.188 respectively. The average family ownership (FOWN) is 29.9 percent. The average board independence (BIND) is 7.10 percent and 24.70 percent of the CEOs of sample firms are also the chairperson of the board (CEODU). The average foreign ownership is 6.7 percent.

TABLE 1 ABOUT HERE 
Table 2 presents the correlation matrix among different variables. This study also obtains variance inflation factors (VIF) for the variables to test for multicollinearity. The reported variance inflation factors of the variables are less than 2 indicating that multicollinearity is not a problem for this study (Neter et al., 1996).

\section{TABLE 2 ABOUT HERE}

The mean values of the explanatory variables included in this paper across the intellectual capital disclosure scores (for both firms with a score higher than the median and those with a score lower than the median) are reported in Table 3. T-test was carried out to examine the statistical significance of the mean differences in the explanatory variables between ICD score (ICDI) higher than the median and ICD score lower than the median of firms. It is observed that firms with an ICD score (ICDI) higher than the median have higher foreign ownership (FOROWN), board independence (BIND), presence of audit committee (AUDCOM). However, firms disclosing less ICD have higher family ownership and more CEO duality. Furthermore, the analysis shows that firm age (FAGE), leverage (LEV), firm size (FSIZE) and profitability (ROA) differ significantly between both groups.

TABLE 3 ABOUT HERE 
Table 4 reports the results of regressing the explanatory variables on the dependent variable ICDI. In first six models this study tests the effect of individual hypothesized variables and in the last model all six variables have been tested. In model 1 this study explores the relation between family ownership (FOWN) and the extent of voluntary disclosure through ICD using a quadratic specification of FOWN variable. This study finds a positive and significant coefficient $(\beta=0.067, \mathrm{p}<0.05)$ of FOWN variable and a negative significant coefficient of FOWN $^{2}(\beta=-$ $0.127, \mathrm{p}<0.05)$ variable. The signs of FOWN and FOWN ${ }^{2}$ imply a broadly non-linear relation between FOWN and the extent of ICD. Thus H1 is supported. This result further implies a positive relation between family ownership and the extent of ICD up to a certain percentage of ownership. This ownership level is estimated to be at 26.40 percent $^{7}$. It is argued that beyond this percentage of ownership family owners get entrenched and managers are relatively less concerned about general shareholders and information transparency resulting in less ICD. It is notable that the finding with regards to family ownership contrasts the findings of Hidalgo et al. (2011) who fail to document any influences of family ownership on the extent of ICD in Mexico.

\section{TABLE 4 ABOUT HERE}


In model 2 the relationship between foreign ownership and the extent of ICD has been tested. This study finds a positive and significant coefficient $(\beta=0.163, \mathrm{p}<0.01)$ of FOROWN (foreign ownership) which implies that higher percentage of foreign ownership results in higher extent of ICD, thus supporting H2. This result suggests that foreign investors demand higher level of corporate ICD due to higher level of information asymmetry. This is consistent with the findings of previous Bangladeshi studies by Khan et al. (2013) who document that foreign ownership positively influences Bangladeshi firms to provide more voluntary disclosures through corporate social responsibilities.

In model 3 the relationship between board independence (BIND) and the extent of ICD has been explored. This study documents a positive and significant coefficient $(\beta=0.286, p<0.01)$ of board independence (BIND) variable suggesting that greater board independence ensures more ICD. This supports H3. Consistent with the findings of previous studies in developed countries (e.g. Li et al., 2008 in UK) this result indicates that independent directors in Bangladesh could act as an internal governance mechanism to reduce agency conflicts between managers and owners through encouraging management to disclose more intellectual capital information. 
The relationship between CEO duality and the extent of ICD is tested in model 4 . This study finds a negative but insignificant coefficient $(\beta=-$ $0.004, p>0.10)$ of CEO duality (CEODU) variable. In other words it implies that CEO duality does not influence the extent of ICD of sample companies. Thus it does not support H4. This result is consistent with Hidalgo, et al. (2011) and Li, et al. (2008). A possible reason for such a finding could be that a person who holds the positions of both Chairperson and CEO in Bangladesh is a family member, so it does not matter whether the two positions are separated.

This study then explores the relationship between family duality and the extent of ICD in model 5 and finds a negative and significant coefficient $(\beta=-0.014, p>0.05)$ of family duality (FAMDU) variable. This result suggests that consistent with $\mathrm{H} 5$ when the positions of $\mathrm{CEO}$ and chairperson are occupied by two persons from the same family, firms provide lower extent of ICD. This finding also implies that when the positions in top management are dominated by the family members, firms tend to focus less on general public resulting in lower extent of voluntary disclosures.

In the next model (model 6) this study examines the effect of presence of audit committee on the extent of ICD and finds a positive and significant coefficient $(\beta=0.044, \mathrm{p}<0.01)$ of audit committee (AUDCOM) 
variable. It suggests that presence of audit committee results in higher level of ICD. This also supports H6. This result further implies that audit committees act as a powerful monitoring device for improving voluntary disclosures such as ICD.

Finally, this study regresses all corporate governance variables on the extent of ICD in model 7 to test the effect of all the hypothesized variables in one model. The results with respect to the coefficients of hypothesized variables are consistent with main findings reported in models 1 to 6 . In regards to control variables, the overall findings suggest that larger (FSIZE), older (LAGE) and better performing (ROA) firms are significantly related to greater extent of ICD. However, this study finds a negative and insignificant effect of leverage on the extent of ICD. The results with respect to the control variables are consistent with the previous studies (see for example, Cerbioni \& Parbonetti, 2007; Li, et al., 2008).

As a part of robustness checks this study also examines the relation between corporate governance attributes and the extent of ICD for different categories of intellectual capital noted earlier in this paper. The results are reported in Table 5. In model 1 this study examines the relation between corporate governance attributes and the extent of internal capital (INTCDI) and finds a positive relation between FOWN 
and the extent of INTCDI followed by a negative relation between these two variables. In other words, a non-linear relation between FOWN and the extent of INTCDI is found. The findings from this analysis also suggest that foreign ownership (FOROWN), board independence (BIND) and presence of audit committee (AUDCOM) have positive effects and family duality (FAMDU) has a negative effect on the extent of internal capital disclosures. However, CEO duality (CEODU) has no significant effect. Firm size (FSIZE), firm age (FAGE) and profitability (ROA) are positively related to the disclosure of internal information while leverage (LEV) is not significantly related.

\section{TABLE 5 ABOUT HERE}

In model 2 this study explores the said relation for the extent of external capital (EXTCDI) and documents a non-linear relation between FOWN and the extent of EXTCDI. This study also finds that external information on intellectual capital disclosure is positively related to board independence (BIND), presence of audit committee (AUDCOM) and foreign ownership (FOROWN). However, a negative and significant coefficient for family duality (FAMDU) is documented. Among the control variables firm size (FSIZE), firm age (FAGE) and profitability (ROA) are positive and significantly related to the extent of external information. 
Finally, in model 3 this study finds a significant non-linear relation between FOWN and the extent of disclosure on human capital (HUMCDI). In particular, this study documents a positive (negative) significant and coefficient of FOWN $\left(\mathrm{FOWN}^{2}\right)$. This study also documents that board independence (BIND) and the presence of audit committee (AUDCOM) are positively linked with the extent of HUMCDI. The findings of this analysis also suggest a negative effect of family duality (FAMDU). However, FOROWN and CEODU are insignificantly related to human capital disclosure. For the control variables this study finds that firm size (FSIZE), firm age (FAGE) and profitability (ROA) have positive influences on human capital disclosure.

Furthermore, this study undertakes a series of robustness checks of the results. First, an OLS regression test was conducted by using the natural logarithm value of the ICD scores as the dependent variable. This study reruns all the models ( 1 to 7 ) and finds that overall results do not differ qualitatively from those contained in Table 4. Second, an OLS regression test was also conducted by dropping all control variables from the model. The results are consistent with the findings reported in Table 4. Finally, this study partitions the sample into two different sub-samples based on time periods - from 2005 to 2006 and from 2007 to 2009 and replicated the original analysis. The purpose of partitioning the sample is 
to test any impact of the 'corporate governance notification 2006' that took place during the study period. The results for the sub-sample periods are qualitatively similar to the results in respect of the whole sample.

\section{Summary and Conclusion}

This study investigated the relationship between different corporate governance attributes and ICD in Bangladesh. It noted that the majority of business enterprises in Bangladesh are family owned organizations and that strong family presences on boards of directors has resulted in the emergence of a culture in which the values of corporate governance mechanisms are not always properly appreciated by management (Al Farooque, Van Zijl, Dunstan, \& Karim, 2007). Similar to many other developing countries, Bangladesh has adopted a rational corporate governance model; however, the traditional structure of its corporate sector is likely to impact on the effectiveness of such mechanisms. In these circumstances, it is expected that the influence of corporate governance mechanisms on the extent of ICD in Bangladesh will be different to those in developed economy settings.

The results of this study suggests that a significant non-linear relationship exists between family ownership and the extent of ICD and implies that as the percentage of family ownership increases, families 
become more entrenched and ICD is adversely affected. This result is consistent with previous studies on family ownership (Anderson \& Reeb, 2004). Notably, in the Mexican context, Hidalgo et al. (2011) found that no significant relationship exists between family ownership and ICD. However, unlike the majority of family owned organization studies (Anderson \& Reeb, 2004; Wang, 2006), Hidalgo et al. (2011) did not examine the non-linear specification of family ownership and, thus, failed to capture the alignment and entrenchment effects that relate to agency problems in family owned companies. By examining the neglected dimension, this study contributes to the stream of literature that examines the relationship between corporate governance and the extent of ICD.

This study also found that a positive and significant relationship exists between foreign ownership and the extent of ICD. The positive effect of foreign ownership implies that foreign investors demand higher ICD due to higher information asymmetry (Haniffa \& Cooke, 2002). It was also found that corporate governance attributes, such as board independence and the presence of an audit committee, have significant and positive effects on the extent of ICD. Thus, it appears that despite traditional settings, corporate governance mechanisms involving presence of outsiders and audit committee have significant influences on the extent 
of ICD made by Bangladeshi companies (Khan, Muttakin, \& Siddiqui, 2013).

Additionally, the results of this study suggest that family duality has a negative and significant effect on the extent of ICD. However, no significant association between CEO duality and the extent of ICD was found. This result is similar to the findings of $\mathrm{Li}$ et al. (2008) and Hidalgo et al. (2011). It should be noted that in Bangladesh, CEO duality may have little impact, as these two roles tend to be occupied by individuals from the same family. To operationalize the CEO duality variable in Bangladesh, this study introduced the variable of family duality to the ICD literature and found that it is negatively related to the extent of ICD.

The overall findings of the study provide empirical evidence that suggests that corporate governance attributes are important determinants of the extent of ICD in developing countries, such as Bangladesh. Thus, in line with previous studies (Cerbioni \& Parbonetti, 2007; Hidalgo, et al., 2011; Li, et al., 2008), empirical confirmation of the conceptual links between corporate governance and intellectual capital, as suggested by Keenan and Aggestam (2001), was provided. The literature was also extended by the introduction of the under researched family ownership dimension and the new variable of family duality, which has not 
previously been considered in ICD research. The results of this study are based on Bangladesh; however, the regulators and policy makers of countries whose corporate ownership and regulatory structures are similar to Bangladesh may also benefit from the findings of this study.

This study, like all studies, has a number of limitations. First, it focused on corporate annual reports and did not consider information from other forms of media, such as websites and independent sustainability reports. However, it should be noted that only a limited number of Bangladeshi companies have websites and independent sustainability reporting is a rare phenomenon in Bangladesh. Second, due to the anticipated problem of a lack of information in collected data sources, this study could only examine a limited number of factors and other factors may exist that influence ICD practices. Third, due to unavailability of some data, this study was unable to directly assess the effectiveness of directors' independence in Bangladesh. However, this an area beyond the scope of current study and future researchers can explore this phenomenon, which may not be limited to Bangladesh.

The findings of this study also give rise to some specific policy implications. The overall findings suggest that in the absence of mandatory disclosure in Bangladesh, internal corporate governance mechanisms could have positive effects on the extent of ICD; that is, 
effective governance mechanisms could reduce information asymmetry through enhanced ICD. Capital market authorities, such as Securities and Exchange Commission, Bangladesh (SECB), may also wish to consider this. Improved ICD practices could also help increase the awareness of intellectual capital in Bangladesh and bodies, such as Intellectual Property Association of Bangladesh, may benefit from this observation. Further, the documented non-linear relationship between family ownership and the extent of ICD implies that SECB could implement regulatory measures, such as limiting family ownership to a certain percentage (e.g., 26.4 percent as in this study), to ensure that family owners do not become entrenched. 


\section{NOTES}

1. Appendix 1 summarizes the features of previous ICD studies in Bangladesh.

2. This mechanism provides both flexibility in the application of the “Corporate Governance Notification" and a means by which compliance will be assessed. Any non-compliance or non-application of a relevant rule could still be said to be consistent with the spirit of the notification. Non-compliances/non-applications are to be monitored by shareholders.

3. Due to institutional pressures, mainly exerted by external aid agencies, Bangladesh has adopted the Anglo-Saxon model of corporate governance. The effectiveness of such corporate governance mechanisms in the context of developing countries has been questioned.

4. Some countries have regulations for ICD; for example, Danish guidelines exist for intellectual capital measurement and reporting, there is also the European project for Measuring Intangibles to Understand and Improve Innovation Management (MERITUM) and the Australian guiding principles on extended performance measurement.

5. We have excluded financial companies since they are controlled by different regulations (such as Banking companies Act, Insurance Companies Act etc.) and are likely to have different disclosure requirements and governance structure. 
6. Two coders in the authors' team have carried out the scoring manually. It has been done independently. Two coders' scores have been reconciled to improve reliability and accuracy. The level of agreement between the two coders has been over $80 \%$ which is considered reliable in content analysis studies (Riffe, Lacy, \& Fico, 2006).

7. $\beta_{1} / 2 \beta_{2}$ Where $\beta_{1=\text { coefficient of }} \beta_{1}, \beta_{2}=$ coefficient of $\beta_{2}$ 


\section{References}

Abeysekera, I. (2008a). Intellectual capital disclosure trends: Singapore and Sri Lanka. Journal of Intellectual Capital, 9(4), 723-737.

Abeysekera, I. (2008b). Motivations behind human capital disclosure in annual reports. Accounting Forum, 32(1), 16-29.

Abeysekera, I., \& Guthrie, J. (2005). An empirical investigation of annual reporting trends of intellectual capital in Sri Lanka. Critical Perspectives on Accounting, 16(3), 151-163.

Abhayawansa, S., \& Azim, M. (2014). Corporate reporting of intellectual capital: evidence from the Bangladeshi pharmaceutical sector. Asian Review of Accounting, 22(2), 98 - 127.

Al-Akra, M., Eddie, I. A., \& Ali, M. J. (2010). The influence of the introduction of accounting disclosure regulation on mandatory disclosure compliance: Evidence from Jordan. The British Accounting Review, 42(3), 170-186.

Al Farooque, O., Van Zijl, T., Dunstan, K., \& Karim, A. (2007). Corporate governance in Bangladesh: link between ownership and financial performance. Corporate Governance: An International Review, 15(6), 1453-1468.

Ali, M.M., Khan, M.H.U.Z., \& Fatima, J.K. (2008). Intellectual capital reporting practices: evidence from Bangladesh. Dhaka University Journal of Business Studies, 29(1), 23-35.

Anderson, R. C., \& Reeb, D. M. (2004). Board composition: Balancing family influence in S\&P 500 firms. Administrative Science Quarterly, 49(2), 209-237.

Arvidsson, S. (2003). The extent of disclosure on intangibles in annual reports. In 4th Annual ANEE Congress. Molle.

Beattie, V., \& Thomson, S. J. (2007). Lifting the lid on the use of content analysis to investigate intellectual capital disclosures. Accounting Forum, 31(2), 129-163.

Botosan, C. A. (1997). Disclosure level and the cost of equity capital. Accounting review, 72(3), 323-349.

Cerbioni, F., \& Parbonetti, A. (2007). Exploring the Effects of Corporate Governance on Intellectual Capital Disclosure: An Analysis of European Biotechnology Companies. European Accounting Review, 16(4), 791826.

Cronbach, L. J. (1951). Coefficient alpha and the internal structure of tests. Psychometrika, 16(3), 297-334.

Fama, E. F., \& Jensen, M. C. (1983). Separation of ownership and control. Journal of law and economics, 301-325.

Finkelstein, S., \& D'aveni, R. A. (1994). CEO duality as a double-edged sword: How boards of directors balance entrenchment avoidance and unity of command. Academy of Management Journal, 37(5), 1079-1108. 
Gul, F. A., \& Leung, S. (2004). Board leadership, outside directors' expertise and voluntary corporate disclosures. Journal of Accounting and public Policy, 23(5), 351-379.

Haniffa, R. M., \& Cooke, T. E. (2002). Culture, corporate governance and disclosure in Malaysian corporations. Abacus, 38(3), 317-349.

Haniffa, R. M., \& Cooke, T. E. (2005). The impact of culture and governance on corporate social reporting. Journal of Accounting and Public Policy, 24(5), 391-430.

Hidalgo, R., García-Meca, E., \& Martínez, I. (2011). Corporate Governance and Intellectual Capital Disclosure. Journal of Business Ethics, 100(3), 483495.

Ho, S. S., \& Shun Wong, K. (2001). A study of the relationship between corporate governance structures and the extent of voluntary disclosure. Journal of International Accounting, Auditing and Taxation, 10(2), 139156.

Inchausti, B. G. (1997). The influence of company characteristics and accounting regulation on information disclosed by Spanish firms. European Accounting Review, 6(1), 45-68.

Jensen, M. C., \& Meckling, W. H. (1976). Theory of the firm: Managerial behavior, agency costs and ownership structure. Journal of Financial Economics, 3(4), 305-360.

Joseph, C., \& Taplin, R. (2011). The measurement of sustainability disclosure: Abundance versus occurrence. Accounting Forum, 35(1), 19-31.

Keenan, J., \& Aggestam, M. (2001). Corporate Governance and Intellectual Capital: some conceptualisations. Corporate Governance: An International Review, 9(4), 259-275.

Khan, M.H.-U.-Z., \& Khan, M.R. (2010). Human capital disclosure practices of top Bangladeshi companies. Journal of Human Resource Costing \& Accounting, 14 (4), 329-349.

Khan, A., Muttakin, M., \& Siddiqui, J. (2013). Corporate Governance and Corporate Social Responsibility Disclosures: Evidence from an Emerging Economy. Journal of Business Ethics, 114(2), 207-223.

Khan, H., \& Ali, M. (2010). An empirical investigation and users' perceptions on intellectual capital reporting in banks: Evidence from Bangladesh. Journal of Human Resource Costing and Accounting, 14(1), 48 - 69.

Li, J., Mangena, M., \& Pike, R. (2012). The effect of audit committee characteristics on intellectual capital disclosure. The British Accounting Review, 44(2), 98-110.

Li, J., Pike, R., \& Haniffa, R. (2008). Intellectual capital disclosure and corporate governance structure in UK firms. Accounting and Business Research, 38(2), 137-159.

Mazumder, M. (2006). Management Accounting for Improved Corporate Governance of Listed Companies. In ICMAB Conference. Dhaka. 
Nahapiet, J., \& Ghoshal, S. (1998). Social Capital, Intellectual Capital, and the Organizational Advantage. The Academy of Management Review, 23(2), 242-266.

Nurhayati, R., Brown, A., \& Tower, G. (2006). Understanding the level of natural environment disclosures by Indonesian listed companies. Journal of the Asia-Pacific Centre for Environmental Accountability, 12(3), 411.

Nurunnabi, M., Hossain, M., \& Hossain, M. (2011). Intellectual capital reporting in a South Asian country: evidence from Bangladesh. Journal of Human Resource Costing \& Accounting, 15(3), 196-233.

Ousama, A. A., Fatima, A.-H., \& Hafiz-Majdi, A. R. (2012). Determinants of intellectual capital reporting: Evidence from annual reports of Malaysian listed companies. Journal of Accounting in Emerging Economies, 2(2), 119-139.

Pomeroy, B., \& Thornton, D. B. (2008). Meta-analysis and the accounting literature: The case of audit committee independence and financial reporting quality. European Accounting Review, 17(2), 305-330.

Prencipe, A., Bar-Yosef, S., Mazzola, P., \& Pozza, L. (2011). Income Smoothing in Family-Controlled Companies: Evidence from Italy. Corporate Governance: An International Review, 19(6), 529-546.

Rashid, A. (2013). Corporate intellectual capital reporting in Bangladesh. International Journal of Learning and Intellectual Capital, 10(2), 107121.

Riffe, D., Lacy, S., \& Fico, F. G. (2006). Analyzing media messages: Using quantitative content analysis in research. London: Routledge.

SEC. (2006). Order relating to Corporate Governance. In SEC/CMRRCD/O206. Dhaka: Securities and Exchange Commission (SEC).

SEC. (2012). Proposed Amendment: Corporate Governance Rules, Securities and Exchange Commission of Bangladesh, No. SEC/CMRRCD/2006158. In. Dhaka: Securities and Exchange Commission (SEC).

Sobhan, F., \& Werner, W. (2003). Diagnostic study of existing corporate governances scenario in Bangladesh. In F. Sobhan \& W. Werner (Eds.), A comparative analysis of corporate governance in South Asia (pp. 3459). Dhaka: Bangladesh Enterprise Institute

Turley, S., \& Zaman, M. (2007). Audit committee effectiveness: informal processes and behavioural effects. Accounting, Auditing \& Accountability Journal, 20(5), 765-788.

Uddin, S., \& Choudhury, J. (2008). Rationality, traditionalism and the state of corporate governance mechanisms: Illustrations from a less-developed country. Accounting, Auditing \& Accountability Journal, 21(7), 10261051.

Villalonga, B., \& Amit, R. (2006). How do family ownership, control and management affect firm value? Journal of Financial Economics, 80(2), 385-417. 
Wang, D. (2006). Founding family ownership and earnings quality. Journal of Accounting Research, 44(3), 619-656. 
Table 1. Descriptive Statistics

\begin{tabular}{lllrrr}
\hline Variables & Mean & Median & Std. Dev. & First Quartile & Third quartile \\
\hline FOWN & 0.299 & 0.342 & 0.221 & 0.067 & 0.497 \\
FOROWN & 0.067 & 0.000 & 0.188 & 0.000 & 0.001 \\
BIND & 0.071 & 0.000 & 0.084 & 0.000 & 0.143 \\
CEODU & 0.247 & 0.000 & 0.432 & 0.000 & 0.000 \\
FAMDU & 0.419 & 0.000 & 0.493 & 0.000 & 1.000 \\
AUDCOM & 0.579 & 1.000 & 0.494 & 0.000 & 1.000 \\
FSIZE & 8.700 & 8.705 & 0.661 & 8.346 & 9.041 \\
FAGE & 23.659 & 24.000 & 10.705 & 14.000 & 30.000 \\
LEV & 0.776 & 0.626 & 0.807 & 0.448 & 0.801 \\
ROA & 0.075 & 0.071 & 0.095 & 0.035 & 0.114 \\
ICDI & 0.155 & 0.125 & 0.103 & 0.086 & 0.219 \\
INTCDI & 0.137 & 0.143 & 0.141 & 0.000 & 0.143 \\
EXTCDI & 0.115 & 0.10 & 0.140 & 0.000 & 0.200 \\
HUMCDI & 0.188 & 0.20 & 0.107 & 0.133 & 0.267 \\
\hline
\end{tabular}

FOWN = percentage of shares owned by the family owners; FOROWN = percentage of shares owned by the foreign investors; BIND = proportion of indirect directors on the board; CEODU = dummy variable equals 1 if same person holds the positions of CEO and chairperson in a firm; FAMDU = dummy variable equals 1 if two persons hold the positions of CEO and chairperson from the same family; AUDCOM= dummy variable equals 1 if there is an audit committee and otherwise 0 ; FSIZE $=$ natural logarithm of total assets; FAGE = natural log of the number of year since the firm's inception; LEV = ratio of book value of total debt and total assets; ROA = ratio of earnings before interest and taxes and total assets; ICDI = Intellectual capital disclosure score/ index; INTCDI = Internal capital disclosure score/ index; EXTCDI= External capital disclosure score/ index; HUMCDI= Human capital disclosure score/ index. 
Table 2. Correlation matrix

\begin{tabular}{|c|c|c|c|c|c|c|c|c|c|c|c|}
\hline Variables & FOWN & FOROWN & $B I N D$ & $C E O D U$ & FAMDU & AUDCCOM & FSIZE & $F A G E$ & $L E V$ & $R O A$ & $V I F$ \\
\hline FOWN & 1.000 & & & & & & & & & & 1.147 \\
\hline FOROWN & $-0.379 * * *$ & 1.000 & & & & & & & & & 1.607 \\
\hline$B I N D$ & -0.057 & $0.264^{* * * *}$ & 1.000 & & & & & & & & 1.869 \\
\hline$C E O D U$ & $0.152 * * *$ & $-0.075^{*}$ & $-0.136^{* * * *}$ & 1.000 & & & & & & & 1.057 \\
\hline$F A M D U$ & $0.584 * * * *$ & $-0.242 * * *$ & 0.071 & -0.478 & 1.000 & & & & & & 1.913 \\
\hline$A U D C C O M$ & 0.009 & $0.167 * * *$ & $0.674 * * *$ & $-0.153 * * *$ & $0.112^{* * *}$ & 1.000 & & & & & 1.782 \\
\hline FSIZE & $-0.374 * * *$ & $0.330 * * *$ & $0.129 * * *$ & -0.030 & $-0.123 * *$ & $0.238^{* * * *}$ & 1.000 & & & & 1.296 \\
\hline$F A G E$ & $-0.234 * * *$ & 0.123 & 0.027 & -0.053 & $-0.187 * * *$ & -0.005 & -0.057 & 1.000 & & & 1.210 \\
\hline$L E V$ & $-0.108 * *$ & $-0.107 * *$ & $-0.125 * * *$ & -0.001 & -0.124 & $-0.143 * *$ & $-0.148 * * *$ & $0.300 * * *$ & 1.000 & & 1.417 \\
\hline$R O A$ & $0.112^{* *}$ & $0.296 * * *$ & $0.186^{* * *}$ & 0.030 & 0.031 & $0.227 * * *$ & $0.156^{* * * *}$ & 0.042 & $-0.401 * * *$ & 1.000 & 1.311 \\
\hline
\end{tabular}

FOWN = percentage of shares owned by the family owners; FOROWN = percentage of shares owned by the foreign investors; BIND = proportion of indirect directors on the board; CEODU = dummy variable equals 1 if same person holds the positions of CEO and chairperson in a firm; FAMDU = dummy variable equals 1 if two persons hold the positions of CEO and chairperson from the same family; AUDCOM= dummy variable equals 1 if there is an audit committee and otherwise 0; FISZE = natural logarithm of total assets; FAGE = natural log of the number of year since the firm's inception; LEV= ratio of book value of total debt and total assets; ROA = ratio of earnings before interest and taxes and total assets; VIF = Variance inflation factor

$*, * *, * * *=$ statistically significant at less than $0.10,0.05$ and 0.01 level. 
Table 3. Differences in the value of the explanatory variables between firms with higher and lower ICDI

\begin{tabular}{lllc}
\hline Variables & ICDI > Median & ICDI < Median & P value \\
\hline FOWN & 0.271 & 0.325 & 0.127 \\
FOROWN & 0.12 & 0.02 & $0.000^{* * *}$ \\
BIND & 0.10 & 0.04 & $0.013^{* *}$ \\
CEODU & 0.19 & 0.30 & $0.000^{* * *}$ \\
FAMDU & 0.413 & 0.464 & $0.037^{* * *}$ \\
AUDCOM & 0.83 & 0.34 & $0.000^{* * *}$ \\
FSIZE & 8.99 & 8.42 & $0.000^{* * *}$ \\
FAGE & 24.56 & 22.78 & $0.046^{*}$ \\
LEV & 0.627 & 0.81 & $0.000^{* * *}$ \\
ROA & 0.097 & 0.05 & $0.000^{* * *}$ \\
\hline
\end{tabular}

FOWN = percentage of shares owned by the family owners; FOROWN = percentage of shares owned by the foreign investors; BIND = proportion of indirect directors on the board; CEODU = dummy variable equals 1 if same person holds the positions of CEO and chairperson in a firm; FAMDU = dummy variable equals 1 if two persons hold the positions of CEO and chairperson from the same family; AUDCOM= dummy variable equals 1 if there is an audit committee and otherwise 0; FISZE = natural logarithm of total assets; FAGE = natural log of the number of year since the firm's inception; LEV= ratio of book value of total debt and total assets; $\mathrm{ROA}=$ ratio of earnings before interest and taxes and total assets; ICDI $=$ Intellectual capital disclosure score/ index.

$*, * *, * * *=$ statistically significant at less than $0.10,0.05$ and 0.01 level. 
Table 4. Relationship between corporate governance attributes and ICDI

\begin{tabular}{|c|c|c|c|c|c|c|c|c|c|c|c|c|c|c|}
\hline & \multicolumn{2}{|c|}{ Model 1 (H1) } & \multicolumn{2}{|c|}{ Model 2(H2) } & \multicolumn{2}{|c|}{ Model 3(H3) } & \multicolumn{2}{|c|}{ Model 4(H4) } & \multicolumn{2}{|c|}{ Model 5(H5) } & \multicolumn{2}{|c|}{ Model 6 (H6) } & \multicolumn{2}{|c|}{ Model 7} \\
\hline & Coefficient & $P$ value & Coefficient & $P$ value & Coefficient & $P$ value & Coefficient & $P$ value & Coefficient & $P$ value & Coefficient & $\begin{array}{r}\mathrm{P} \\
\text { value }\end{array}$ & Coefficient & $\begin{array}{r}P \\
\text { value }\end{array}$ \\
\hline Intercept & -0.321 & $0.000^{* * *}$ & -0.419 & $0.000 * * *$ & -0.544 & $0.000 * * *$ & -0.549 & $0.000^{* * * *}$ & -0.539 & $0.000 * * *$ & -0.520 & $0.000 * * *$ & -0.416 & $0.000^{* * * *}$ \\
\hline FOWN & 0.067 & $0.018 * *$ & & & & & & & & & & & 0.208 & $0.000^{* * *}$ \\
\hline$F O W N^{2}$ & -0.127 & $0.039^{* *}$ & & & & & & & & & & & -0.342 & $0.000^{* * * *}$ \\
\hline FOROWN & & & 0.163 & $0.000 * * *$ & & & & & & & & & 0.117 & $0.000^{* * * *}$ \\
\hline BIND & & & & & 0.286 & $0.000^{* * * *}$ & & & & & & & 0.197 & $0.000^{* * * *}$ \\
\hline CEODU & & & & & & & -0.004 & 0.599 & & & & & -0.019 & 0.354 \\
\hline$F A M D U$ & & & & & & & & & -0.014 & $0.035^{* *}$ & & & -0.026 & $0.014 * *$ \\
\hline AUDCOM & & & & & & & & & & & 0.044 & $0.000 * * *$ & 0.045 & $0.000 * * *$ \\
\hline FSIZE & 0.071 & $0.000 * * *$ & 0.054 & $0.000 * * *$ & 0.068 & $0.000 * * *$ & 0.069 & $0.000^{* * * *}$ & 0.073 & $0.000^{* * * *}$ & 0.065 & $0.000 * * *$ & 0.054 & $0.000^{* * * *}$ \\
\hline$F A G E$ & 0.001 & $0.000 * * *$ & 0.002 & $0.000 * * *$ & 0.002 & $0.000^{* * * *}$ & 0.002 & $0.000 * * *$ & 0.001 & $0.000^{* * * *}$ & 0.002 & $0.000^{* * *}$ & 0.001 & $0.000 * * *$ \\
\hline$L E V$ & -0.006 & 0.175 & -0.008 & $0.037 * *$ & -0.005 & 0.173 & -0.008 & $0.072^{*}$ & -0.007 & 0.106 & -0.007 & $0.086^{*}$ & -0.004 & 0.212 \\
\hline $\begin{array}{l}\text { ROA } \\
\text { Industry }\end{array}$ & 0.263 & $0.000^{* * * *}$ & 0.137 & $0.000^{* * *}$ & 0.176 & $0.000^{* * * *}$ & 0.222 & $0.000^{* * *}$ & 0.231 & $0.000^{* * * *}$ & 0.178 & $0.000^{* * *}$ & 0.117 & $0.000^{* * *}$ \\
\hline dummy & Yes & & Yes & & Yes & & Yes & & Yes & & Yes & & Yes & \\
\hline Year dummy & Yes & & Yes & & Yes & & Yes & & Yes & & Yes & & Yes & \\
\hline Adjusted $R^{2}$ & 0.467 & & 0.609 & & 0.576 & & 0.539 & & 0.445 & & 0.564 & & 0.632 & \\
\hline F stat & 19.447 & & 57.151 & & 50.000 & & 43.085 & & 42.957 & & 47.616 & & 53.972 & \\
\hline
\end{tabular}

FOWN = percentage of shares owned by the family owners; $F O W N^{2}=$ Square of FOWN variable; FOROWN = percentage of shares owned by the foreign investors; BIND = proportion of indirect directors on the board; CEODU = dummy variable equals 1 if same person holds the positions of CEO and chairperson in a firm; FAMDU = dummy variable equals 1 if two persons hold the positions of CEO and chairperson from the same family; AUDCOM= dummy variable equals 1 if there is an audit committee and otherwise 0 ; FISZE = natural logarithm of total assets; FAGE = natural log of the number of year since the firm's inception; LEV= ratio of 
book value of total debt and total assets; ROA = ratio of earnings before interest and taxes and total assets. ICDI = Intellectual capital disclosure score/ index. *, **, $* * *=$ statistically significant at less than $0.10,0.05$ and 0.01 level. 
Table 5. Relationship between corporate governance attributes and different categories of intellectual capital

\begin{tabular}{|c|c|c|c|c|c|c|}
\hline & \multirow{2}{*}{\multicolumn{2}{|c|}{ Model 1(INTCDI) }} & \multicolumn{2}{|c|}{ Model 2 (EXTCDI) } & \multicolumn{2}{|c|}{ Model 3 (HUMCDI) } \\
\hline & & & & & & \\
\hline & Coefficient & value & Coefficient & $\mathrm{P}$ value & Coefficient & value \\
\hline Intercept & -0.422 & $0.000 * * *$ & -0.478 & $0.000 * * *$ & -0.372 & $0.000 * * *$ \\
\hline FOWN & 0.301 & $0.000 * * *$ & 0.337 & $0.000 * * *$ & 0.081 & $0.023 * *$ \\
\hline$F O W N^{2}$ & -0.475 & $0.000 * * *$ & -0.469 & $0.000 * * *$ & -0.195 & $0.029 * *$ \\
\hline FOROWN & 0.063 & $0.044 * *$ & 0.299 & $0.000 * * *$ & 0.021 & 0.365 \\
\hline$B I N D$ & 0.184 & $0.018 * *$ & 0.275 & $0.000 * * *$ & 0.151 & $0.011^{* *}$ \\
\hline$C E O D U$ & -0.021 & 0.203 & -0.046 & 0.623 & -0.001 & 0.891 \\
\hline FAMDU & -0.035 & $0.047 * *$ & -0.014 & $0.001 * * *$ & -0.029 & $0.027 * *$ \\
\hline$A U D C O M$ & 0.073 & $0.000 * * *$ & 0.032 & $0.005^{* *}$ & 0.039 & $0.001 * * *$ \\
\hline FSIZE & 0.053 & $0.000 * * *$ & 0.054 & $0.000 * * *$ & 0.056 & $0.000 * * *$ \\
\hline FAGE & 0.002 & $0.000 * * *$ & 0.001 & $0.000 * * *$ & 0.001 & $0.000 * * *$ \\
\hline$L E V$ & -0.014 & 0.122 & -0.001 & 0.852 & -0.006 & 0.275 \\
\hline$R O A$ & 0.132 & $0.029 * *$ & 0.108 & $0.055^{*}$ & 0.122 & $0.007 * * *$ \\
\hline \multicolumn{7}{|l|}{ Industry } \\
\hline dummy & Yes & & Yes & & Yes & \\
\hline Year dummy & Yes & & Yes & & Yes & \\
\hline Adjusted $R^{2}$ & 0.398 & & 0.542 & & 0.399 & \\
\hline$F$-statistic & 23.479 & & 41.179 & & 23.583 & \\
\hline
\end{tabular}

FOWN $=$ percentage of shares owned by the family owners; $F O W N^{2}=$ Square of FOWN variable; FOROWN = percentage of shares owned by the foreign investors; $\mathrm{BIND}=$ proportion of indirect directors on the board; CEODU = dummy variable equals 1 if same person holds the positions of CEO and chairperson in a firm; FAMDU = dummy variable equals 1 if two persons hold the positions of CEO and chairperson from the same family; AUDCOM= dummy variable equals 1 if there is an audit committee and otherwise 0 ; FISZE $=$ natural logarithm of total assets; FAGE $=$ natural $\log$ of the number of year since the firm's inception; $\mathrm{LEV}=$ ratio of book value of total debt and total assets; $\mathrm{ROA}=$ ratio of earnings before interest and taxes and total assets; INTCDI = Internal capital disclosure score/ index; EXTCDI= External capital disclosure score/ index; HUMCDI= Human capital disclosure score/ index. $*, * *, * * *=$ statistically significant at less than $0.10,0.05$ and 0.01 level. 
APPENDIX I

The key features of prior ICD studies in Bangladesh

\begin{tabular}{|c|c|c|c|}
\hline Study & Sample & Research Objective & Findings \\
\hline $\begin{array}{l}\text { Abhayawansa } \\
\text { and Azim } \\
\text { (2014) }\end{array}$ & $\begin{array}{l}16 \\
\text { pharmaceutical } \\
\text { companies }\end{array}$ & $\begin{array}{l}\text { Extent of } \\
\text { disclosure }\end{array}$ & $\begin{array}{l}\text { There is a lack of awareness among the } \\
\text { pharmaceutical companies of the significance of } \\
\text { IC in corporate value creation and a commitment } \\
\text { to publicly communicating IC. These companies } \\
\text { did not adopt a consistent framework for IC } \\
\text { reporting and they did not properly measure and } \\
\text { manage their IC. }\end{array}$ \\
\hline $\begin{array}{l}\text { Rashid } \\
(2013)\end{array}$ & $\begin{array}{l}136 \text { non- } \\
\text { financial listed } \\
\text { companies }\end{array}$ & $\begin{array}{l}\text { Extent of } \\
\text { disclosure }\end{array}$ & $\begin{array}{l}\text { ICD practices are very limited and there is an } \\
\text { increasing trend of such reporting over the years. } \\
\text { Most notable disclosure attribute was the human } \\
\text { capital reporting. }\end{array}$ \\
\hline $\begin{array}{l}\text { Nurunnabi et } \\
\text { al. }(2011)\end{array}$ & $\begin{array}{l}90 \text { non- } \\
\text { financial listed } \\
\text { companies }\end{array}$ & $\begin{array}{l}\text { Relationship } \\
\text { between extent } \\
\text { of disclosures } \\
\text { and various } \\
\text { corporate } \\
\text { characteristics. }\end{array}$ & $\begin{array}{l}\text { ICD is very limited. Furthermore, size and } \\
\text { industry are important attributes to explain the IC } \\
\text { disclosure (ICD). }\end{array}$ \\
\hline $\begin{array}{l}\text { Khan and Ali } \\
(2010)\end{array}$ & $\begin{array}{l}20 \text { selected } \\
\text { listed banking } \\
\text { companies }\end{array}$ & $\begin{array}{l}\text { Extent of } \\
\text { disclosure }\end{array}$ & $\begin{array}{l}\text { The banking companies disclosed considerably } \\
\text { more human resource items than other categories } \\
\text { of IC items. Moreover, the reporting of IC is }\end{array}$ \\
\hline
\end{tabular}


narrative rather than numerical terms.

Khan and

Khan (2010)

(2008)

\section{2 listed}

manufacturing

and service

companies

22 listed non-

financial

companies
Extent of

disclosure

tof

disclosure

Human capital (HC) reporting in the annual report is insufficient since some items such as employee incentives programmes, employee value, $\mathrm{HC}$ statistics (such as profitability per employee, sales per employee), employee skill and competence profiles, etc. were almost completely absent among the sample of firms.

Companies disclose lower extent of IC. Further, IC reporting is limited to qualitative form rather than in quantitative form. 


\section{Appendix II \\ Intellectual capital disclosure checklist}

\section{Internal capital category \\ 1. Intellectual properties \\ 2. Management philosophy \\ 3. Corporate culture \\ 4. Processes \\ 5. Systems \\ 6. Networking}

7. Financial relations

II. External capital category

1. Brand

2. Customer satisfaction and loyalty

3. Quality standards

4. Company image/ reputation

5. Favourable contract

6. Business collaborations

7. Licensing agreements

8. Franchising agreements

9. Distribution channels

10.Market share

\section{Human capital category}

1. Number of employees

2. Know-how

3. Vocational qualifications

4. Employee training

5. Employee education

6 . Work related knowledge

7. Entrepreneurial spirit, innovativeness

8. Union activity

9. Employee thanked

10. Employee involvement in the community

11.Employee share and option scheme
It is a term that encompasses patents, copyrights, trademarks, trade secrets, licenses, commercial rights and other related fields. The way leaders in the firm think about and its employees i.e. the way a firm is managed.

Specific reference to working culture.

Management or technical processes implemented

Information systems.

The systems available in a firm that allows interaction of people via a broad array of communication media and devices.

Defined as a favourable relationships the firm has with investors, banks, and other financiers, financial rating, financial facilities available, and listings.

Description of brands owned/bought by the firm.

Reference to overall satisfaction of customers Includes ISO accreditations, reference to quality initiatives. It refers to the perception of a firm by the stakeholders. Favourable contract signed.

Reference to informal collaborations with business partners which did not lead to formal agreements.

Any partnership or collaborative agreements with other firms Any franchise agreements signed.

Reference to supply chain management and distribution.

Any mention of product/division market share or competitive Position.

Clear detail of total number of employees.

Description of knowledge, know-how, expertise or skills of directors and other employees.

Additional qualification held by employees and directors.

Any mention of training programme.

Education of directors as well as other employees.

It mainly relates to knowledge that employees have related to their current job description, including employees' previous working experiences.

It refers to employee engagement, empowerment, and creativity.

Trade union relations.

Thanks given to the employee.

Company and employee involvement in community based activities

Employee share and option ownership plan 
12.Employee benefits

13 Profit sharing

14. Health and safety

15.Equity issues
Employee benefits such as provident fund, gratuity and group Insurance.

Employee profit sharing.

Employee occupational health and safety.

Equity issues such as race, gender, disability and ethnic group 